\title{
Development and Negative Constructions \\ of Ethnic Identity: Responses to Asian \\ Fisheries Investment in the Pacific
}

Kate Barclay

Ethnicity may take shape through state-led purposeful schemes of nation building. It also takes shape, however, through a multitude of banal, daily encounters. The interactions that help shape people's senses of their own (and others') ethnicities often take place in the context of mundane errands conducted through state institutions, such as post offices, which may, for example, display national flags (Billig I995). In countries such as those in Melanesia with relatively weak states and where people have correspondingly less interaction with state institutions, the encounters that cumulatively build senses of nationhood may equally be with international organizations, such as aid donors, nongovernmental organizations (NGOS), and corporations (Foster 2002).

This article explores ethnic identity in Solomon Islands and Papua New Guinea as it arises through engagement with two tuna fishing and canning companies: Solomon Taiyo Ltd and RD Tuna. Solomon Taiyo Ltd, based in Noro in the Western Province of Solomon Islands (map I), was established in 1973 by Japanese fishing giant Taiyō Gyogyō Kabushiki Kaisha (renamed Maruha Corporation in 1993) and the Solomon Islands government. The company was the largest private sector employer in the country and one of the largest exporters, second only to the logging sector. In 2000 the company employed around 2,500 Solomon Islanders, but changes in the global tuna market and Maruha's corporate strategy resulted in the Japanese partner withdrawing; operations subsequently continued under government ownership as Soltai Fishing and Processing Ltd. RD Tuna, wholly owned by a Filipino company, started in Madang in 1997, and foreign investment is ongoing (map 2). Papua New Guinea's cash economy is much larger than that of Solomon Islands and is dominated by the logging

The Contemporary Pacific, Volume 24, Number I, 33-63

(C) 2012 by University of Hawai'i Press 
and mining sectors, so RD Tuna has not been as important in the national economy as Solomon Taiyo was to the Solomons. But RD Tuna is nevertheless economically significant, especially in the Madang area, and has a workforce of around 3,000 Papua New Guineans. Both companies have been important symbols of national economic progress but were also troubling as such because, instead of demonstrating a fully indigenous capacity to succeed in the global tuna industry, they were led by foreign investors. Local citizens' daily encounters with the companies occurred through contact with the fishing vessels and crews in ports and fishing areas, and through people's roles as employees, consumers of the companies' products, and contractors of services to the companies. Representations of the companies in public discourse reveal the kinds of national identity built through these encounters and in the context of wider social influences, such as histories of colonialism, ongoing struggles with development, and domestic politics.

The thinking behind this article evolved from a discovery during my fieldwork on Solomon Taiyo in I999. I was tracing evidence for complaints against the company and found, contrary to my expectations, that the company was behaving more socially and environmentally responsibly than prevalent public opinion about the company had led me to believe. For example, it was often assumed that Solomon Taiyo was depleting tuna stocks, whereas its practice of pole-and-line fishing for skipjack is actually one of the most environmentally friendly types of industrial tuna fishery (Stone, Toribau, and Tolvanen 2009). Not all complaints were erroneous, but in general the representations of Solomon Taiyo as a corporate wrongdoer went beyond the available evidence. Later research on RD Tuna revealed a similar pattern; while there were certainly grounds for complaint, the magnitude of the complaints often exceeded them. I have explored the main complaints and the evidence for them in previous publications (Barclay and Cartwright 2007; Barclay 2008). This is not to say that my preconception that the companies were bad corporate citizens was replaced by a belief that they were good corporate citizens. Rather, I found that local people experienced a range of positive and negative effects from the operations of these companies and that, on close reading of people's reactions to the companies, their opinions of the companies could best be described as ambivalent (Barclay 2008). This, however, was on close reading. The fact remains that the foregrounded opinion of the two companies is generally negative.

In light of this, complaints against these companies may be under- 


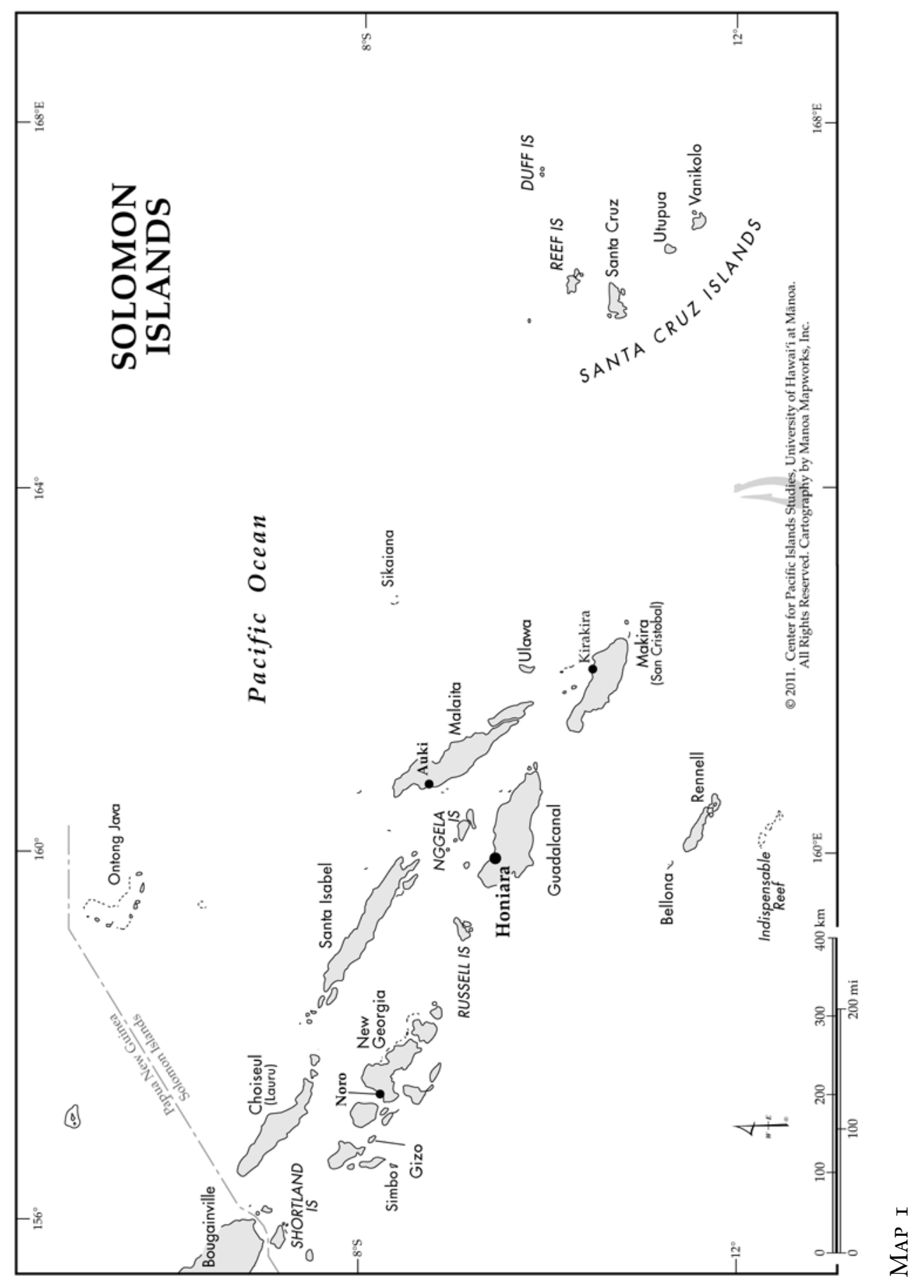




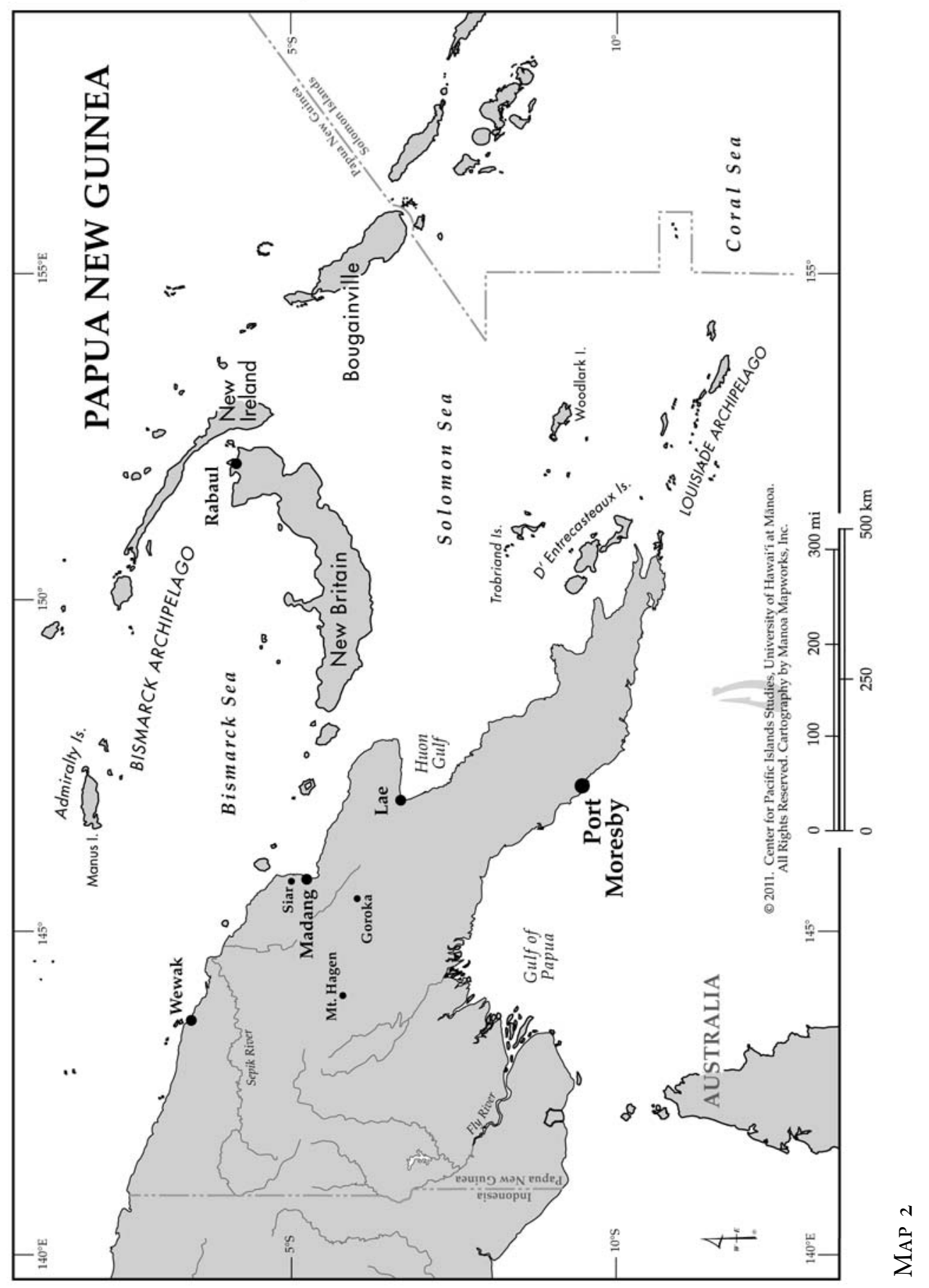


stood as representations, reflecting the worldviews of the people involved, including identifications of self and others. ${ }^{1}$ Elsewhere I have explored this idea for Japanese, white, and Okinawan identities (Barclay 2006, 2007). ${ }^{2}$ The aim of this article is to investigate representations of Solomon Taiyo and RD Tuna to reveal aspects of Solomon Islander and Papua New Guinean identities.

The expectation that foreign investors will not act in the best interests of the host society is prevalent everywhere, not just in the Pacific Islands. Can an analysis of stories of corporate wrongdoing by foreign investors, therefore, add anything to our understandings of Solomon Islander and Papua New Guinean identities in particular? Broadly speaking, antipathy to foreign investors may arise from xenophobia, which can exist in any ethnic group; however, the precise nature of responses to foreign investors is colored by specific histories of relations with outsiders. The first part of this article looks at the kinds of national identity visible in representations of Solomon Taiyo and RD Tuna and finds that they exhibit a "frog perspective," that is, a sense of looking up at the world from a subordinate position. This may be seen as the result of Solomon Islands' and Papua New Guinea's colonial past and ongoing status as "least-developed nations." Another aspect of local identities as they emerge in representations of Solomon Taiyo and RD Tuna is that they are negatively constructed to contrast with external Others who are seen as detrimental to the in-group. In other words, strong economic nationalism is exhibited in representations of these companies, but this nationalism is not based in a sense of shared culture or race, or in shared purpose toward a goal; it is more a reaction against outsiders than a binding together of insiders. The kind of local identity visible in complaints against Solomon Taiyo and RD Tuna is one of sufferers of "negative impacts." These companies are understood as vehicles through which powerful foreigners exploit vulnerable locals, and national identity emerges through this experience. "Negative impact" is a discourse through which specific kinds of Solomon Islander and Papua New Guinean identities are reproduced.

The second part of the article looks at what negative impact identification has meant for Solomon Islanders and Papua New Guineans in their struggles over the development these companies are supposed to bring. Stories of negative impact from Solomon Taiyo and RD Tuna have served a variety of social and political purposes, one of which is as a form of resistance against companies that have brought social and environmental problems without all of the hoped-for benefits of modernity. On the other 
hand, identifying as negatively impacted also constitutes a form of victim identification. Furthermore, the discourse of negative impact is often polemical—completely rejecting the development introduced by Solomon Taiyo and RD Tuna-even though people's actual engagement with these companies is much more complex. Solomon Islanders and Papua New Guineans generally want the health and wealth benefits of modernity but also want to retain valued parts of indigenous culture and ways of lifelocally appropriate versions of modernity. Discourses of negative impact risk falling into the rut of tired old pro- and antidevelopment arguments, which obscure more important questions about what people want from these companies and how their wants might be satisfied. Creating locally appropriate forms of modernity may involve moving beyond identifying as negatively impacted to other ways of relating to foreign investors.

\title{
IDENTITY RePRoduction THROUgh StORIES OF Negative IMPACT
}

Public representations of Solomon Taiyo and RD Tuna have often been strikingly negative. The following poem contains a word play on the name of Solomon Taiyo's best-selling local product "Solomon Blue" (figure I). The poem expresses public perceptions of Solomon Taiyo that were prevalent during its nearly three decades of operation.

\author{
Solomon Blue \\ You reap a harvest \\ you did not plant \\ You drain my resources \\ in the name of development \\ You fish in my waters \\ for bonito \\ You pay me a little \\ for permission \\ You process your catch \\ compressed into cans \\ You pour back your waste into our seas \\ Pollution! \\ Then you sell back to me, \\ at a profit \\ Solomon Blue \\ Jully Sipolo, "Praying Parents"
}


The following extract from a website reflects widespread perceptions of RD Tuna in Papua New Guinea:

Members of the Kananam community (Madang, Papua New Guinea) have formed the Idawad Association to protest the development of a huge tuna cannery on their land. The wholly Filipino owned company R.D. Tuna have gained access to a wharf facility on Kananam land, after a land deal with the Catholic Church and the Madang Provincial Government carried out behind the backs of Kananam landowners ... Kananam leaders such as James Sungai and Francis Gem are furious, and point out that the cannery and wharf facility are seriously polluting their lagoon, wetlands, water and air, workers are very lowly paid (less than us\$2/day) and union organisers have been sacked. R.D. Tuna ships are encouraging a prostitution trade in the Kananam community. All senior managers are Filipino, and all profits are sent to the Philippines. R.D. Tuna pays NO tax in PNG. JOIN THE INTERNATIONAL CAMPAIGN TO SUPORT [sic] THE KANANAM COMMUNITY! BOYCOTT RD TUNA PRODUCTS! (Friends of Kananam nd)

Both extracts air negative views (as opposed to ambivalent views) about the type of development brought about by the fishing and processing operations. They also portray oppositional relations between "us" and "them," with the companies as "them."

Representations of both companies have often made strong connections between negative effects of operations and foreign ownership of the com-

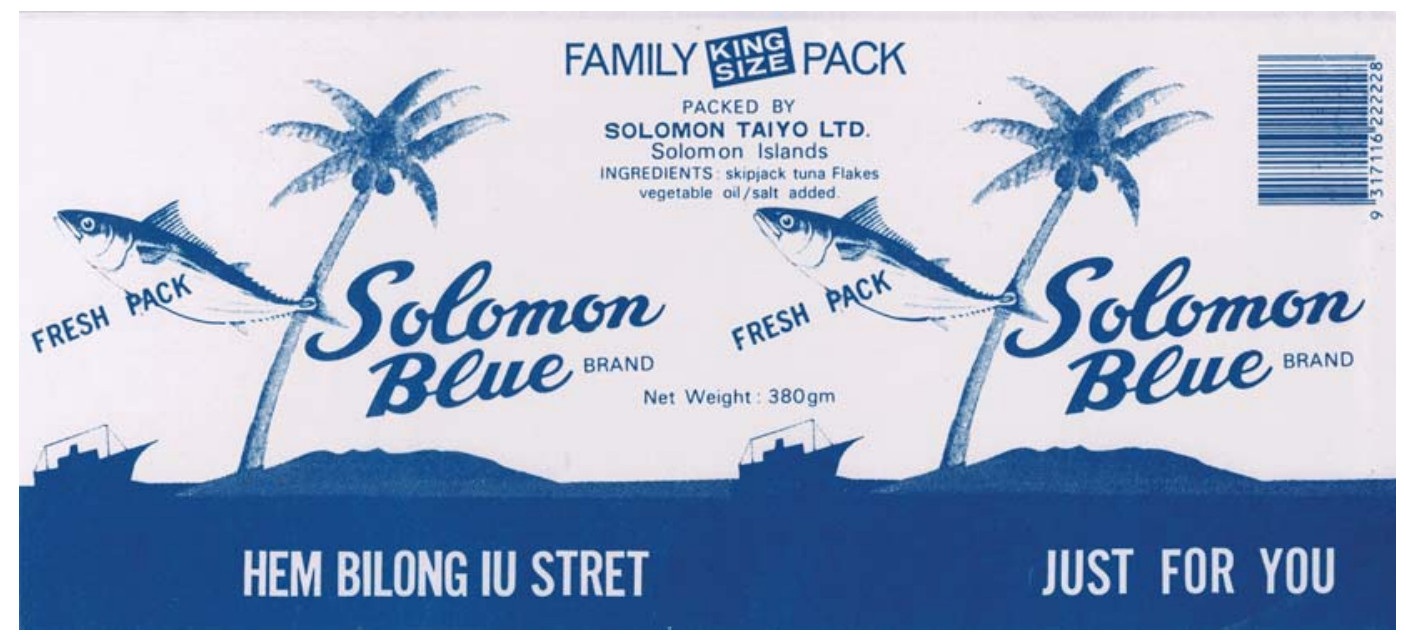

FigURE I Solomon Blue canned flake tuna label. Reproduced with permission. 
panies or foreigners employed by the companies. For example, NGO leader Panatina told me about the sexual relations taking place between male crewmembers from Solomon Taiyo fishing boats and women in villages near baitfishing grounds, relations that were frequently cited as one of the company's main negative impacts. She said: "We can't regulate the sex life of the people," but perhaps "a policy or something could be written down so foreigners don't do this." ${ }^{3}$ Church leaders and town officials expressed concern about prostitution around the Solomon Taiyo factory in Noro along similarly nationalist (and patriarchal) lines, describing it as "selling women to foreigners." "The matron at the Noro Women's Hostel, home to many cannery workers, said that sometimes men came to the hostel asking for access to the women who lived there, and her response to them was that she was "not selling Solomon Islanders." 5

An interesting element in these depictions is the prominent role given to foreigners. Solomon Islander crewmembers had outnumbered foreigners (mostly Okinawans) on Solomon Taiyo vessels since the I980s, and by the late I 990 os more than 90 percent of crews were Solomon Islanders. Interviews, fieldwork observations, and documentary evidence indicated that Solomon Islander crewmembers were just as likely as Okinawan crewmembers to engage in sexual relations with villagers, with just as many attendant problems of unplanned pregnancies and alcohol-fueled violence (Barclay 2008). As I probed beyond their initial representations, my interviewees also acknowledged the active roles played by Solomon Islanders. The matron of the Women's Hostel said Solomon Islander as well as foreign men approached the hostel. Village elder Kindu started out her interview by saying that when Solomon Taiyo vessels first came to fish near her village, she was very unhappy with the Japanese crewmembers coming ashore and "chasing" local women. As her interview progressed, however, she said that local women also "chased" the foreign fishermen, and that women's families might facilitate such relationships because the Okinawan fishermen were generous with store-bought goods. ${ }^{6}$ The first and most prominent stories about social problems associated with Solomon Taiyo, however, usually presented unsanctioned sexual liaisons as something foreign men did to local women.

Why would Solomon Islanders perceive social problems associated with Solomon Taiyo in this way? I propose that stories about social problems, including the tendency to foreground foreigners in representations of these problems, are part of a widespread discourse of development in Solomon Islands. This discourse, like all discourses in all societies, is colored by the 
social relations and identities of the people involved, corresponding with the roles attributed to different groups in the discourse.

Representations such as those above tend to portray locals as passive "impactees" and foreigners as active impactors. Relations between locals and foreigners are portrayed as hierarchical, with locals subordinated. As mentioned earlier, postcolonial scholars have argued that colonial histories of racism and domination have caused nonwhite peoples to have a "frog perspective." Richard Wright, drawing on Nietzsche, described oppressed subjectivity as an "angle of vision-an outlook of people looking upward from below" (paraphrased by Gilroy I993, I60-I6I). This phenomenon has also been called "colonialism of the mind" (Nandy I988). Critical development theorists argue that contemporary relations of economic assistance perpetuate this kind of hierarchical identification between development donors (many being former colonizers, including Japan) and recipients (many being former colonies) (Sachs I997). Some researchers have found that the experience of having been colonized may heighten sensitivity that foreign investment could lead to exploitation (Cherry 2006). Such sensitivity seems to be exhibited in Solomon Islander and Papua New Guinean responses to Asian fisheries investment.

Was the "Asianness" of the investment a significant contributing factor in the negativity with which these companies were portrayed? There is anti-Asian sentiment in both societies, evidenced by anti-Chinese riots against the Ramu NiCo nickel mine in Papua New Guinea in 2009 and riots targeting ethnic Chinese businesses in Honiara in 2006, both of which harnessed ongoing resentment of the greater wealth and the cultural and business practices of local Chinese communities (Crocombe 2007; Atkinson 2009). Judith Bennett traced the history of anti-Chinese sentiment in Solomon Islands and found that a significant contributing factor was white colonial bad-mouthing of Chinese, whom they portrayed as exploitative and morally corrupting of Islanders. Bennett noted that there was no evidence that the Chinese were any more exploitative of locals than were white colonials. The explanation for white denunciations of Chinese influences seems to be that white people were threatened in their dominance of business because Chinese traders and eating houses offered cheaper goods and a more inviting atmosphere to locals than did the trade stores and clubs owned by whites (Bennett I987, 206-209). Contemporary involvement of the People's Republic of China (PRC) in Africa is likewise denounced by Western commentators as corrupting and exploitative, but Chinese involvement in Africa arguably follows the pat- 
tern of the capitalist world system and is very similar to (not worse than) ongoing Western involvement (Sautman and Yan 2008). Joel Atkinson has shown how unfounded accusations by Australian officials against Taiwanese influence in domestic politics entered Solomon Islander discourse about the Taiwanese via English-language media (2009). Negative characterizations of Chinese are sometimes extended to Asians as a whole in the Pacific, across the disparate groups of "old" and "new" Chinese immigrants, Taiwanese, Chinese Malaysians, Japanese, Okinawans, Koreans, and Filipinos. ${ }^{7}$ Fishing in the Pacific is often lumped with logging and mining in being seen as unsustainable extractive industries dominated by Asian companies. The anti-Asian attitudes apparent in some representations of Solomon Taiyo and RD Tuna should be understood in this light-as being influenced by a range of factors beyond actual actions by Asians. Furthermore, the existence of anti-Asian sentiments in representations of fisheries investment should not be taken to mean that Papua New Guineans and Solomon Islanders only opposed the companies because they were Asian. White colonialism is within living memory, and Western multinational corporations are seen as equally likely to cause negative impacts (Barclay 2007).

The tendency to foreground the role of foreigners in problems arising from the companies, therefore, could be seen as a reflection of national identities in Solomon Islands and Papua New Guinea. Global discourses of race as well as of Third World exploitation at the hands of foreign companies are woven into the Solomon Islander and Papua New Guinean nationalisms evident in representations of Solomon Taiyo and RD Tuna. This comes through clearly in excerpts from a letter to the editor of the Solomon Star about Solomon Taiyo. Written by "a concerned nationalist," the letter described the company as operating under a "blueprint of Japanese imperialism" and noted that there were no Japanese workers in the factory, only "Black faces"; local workers were described as "human tools" and "unskilled, half educated cheap labour." The letter writer accused Solomon Taiyo of taking fish resources "without equitable returns to us people of Munda and the whole nation." The writer described Solomon Taiyo as a "crime against our people" and concluded that "we do not need such development" (Solomon Star 1995).

The tendency to view company activities in terms of a nationalist us/ them dichotomy pervaded all sorts of representations of Solomon Taiyo. When discussing the company's regional marketing strategy, the deputy general manager said he expected that Fijian consumers would prefer to 
buy PAFCO tuna to support their local industry. He said Solomon Taiyo should not market aggressively in Fiji and "upset their own rightful market" because "once nationalistic feeling comes in, of course, it is better that they go for their own canned tuna than [for] someone else's." 8 When discussing with NGO leader Panatina the differences between ways women and men use income, I mentioned that Okinawan fishermen's wives had control of the money earned through Solomon Taiyo and tended to use it for the benefit of the family as a whole (such as for improvements in housing and education). Panatina, however, saw quite a different meaning in this story; she reacted bitterly to hearing that money earned by Okinawans in Solomon Islands went overseas. ${ }^{9}$

There was also a strong element of economic nationalism in representations of foreign fisheries investment in Papua New Guinea. Peter Donigi, former PNG permanent representative to the United Nations, wrote a piece published in The National advocating that foreigners not be allowed to fish in PNG waters. Aid should be used to help the PNG government buy a fishing fleet so Papua New Guineans could fish themselves and trade their way out of least-developed country status (Donigi 2005). In representations of RD Tuna, a national "we" was most evident in debates over the levels of localization in the workforce, reflecting a widespread belief that foreigners were taking jobs that should have gone to Papua New Guineans. An investigation into RD Tuna's localization was launched by Prime Minister Michael Somare in 2003 (Frank and Naisi 2003). ${ }^{10}$

The fact that "local" is usually understood as Solomon Islander or Papua New Guinean in these representations is interesting, because subnational ethnic identities are often far more prominent than national ones in Papua New Guinea and Solomon Islands. Indeed, these countries are usually noted for their lack of national identity. Subnational rivalries dominate the PNG political agenda, and national economic development strategies are often weakened by the political necessity to distribute projects across regional groupings (Reilly 2008). In Solomon Islands there is much friction between groups from the island of Malaita and groups from other parts of the country. Tensions between Malaitan settlers and local people around the capital Honiara on the island of Guadalcanal sparked the social unrest that caused the Solomon Islands state to fail between 2000 and 2003. Christine Dureau has argued that Solomon Islands nationalism is fractured because people from the west of the country did not have the same anticolonial experiences as people from the east, due to struggles 
such as the Maasina Rule movement, which was centered in Malaita in the years following World War II (Dureau I998).

Subnational rivalry was a strong element in the politics surrounding Solomon Taiyo. It was addressed in company policies to prevent consolidation of any one island group in particular work areas, and in exhortations for employees to "look after wantoks (kinship groups) after hours"that is, not to bring these loyalties into the workplace. Complaints about Solomon Taiyo from people from the Western Province included protests that the company employed too many easterners (particularly Malaitans) when the company's location in the west of the country meant westerners should have priority, and that easterners should not be encouraged to migrate to the west. Subnational identities, however, were relatively less important than national identification in the sense of exploitation at the hands of Solomon Taiyo. There were obvious disparities in pay and seniority between Solomon Islanders and expatriate employees within the company, whereas there was no clear structural discrimination between island groups (Barclay 2004).

Significant subnational politics were also at play in some of the public complaints against RD Tuna. A widely cited social impact assessment of the company presented the perspectives of groups from the Madang area of Papua New Guinea who had lost their land when it had been alienated during the colonial era for a Church mission and had since been occupied by RD Tuna (Sullivan and others 2003). These people were left without land for growing food, which made them significantly disadvantaged compared to most other Papua New Guineans. The social impact study, and the representations of $\mathrm{RD}$ Tuna by nongovernmental organizations drawing on that study, argued that these dispossessed people should have priority for benefits from the company in terms of employment, training, and ownership of spin-off businesses doing cleaning, transport, and stevedoring for RD Tuna. From this perspective, the salient "we" constructed against RD Tuna (and against the government, the Church, and other Papua New Guineans who might take these opportunities) referred to the dispossessed groups, not Papua New Guineans as a whole. This perspective, however, was only relevant to the displaced groups in the Siar area of Madang Province (see map 2) and did not displace the nationalism with which many viewed RD Tuna.

Class is another kind of grouping of interests and identities that cuts across national identity in representations of Solomon Taiyo and RD Tuna. Different class groups did not align with distinct representations of these 
companies. Villagers, waged workers, managers, public servants, and politicians all foregrounded criticisms in representations of the companies, relating similar stories about negative social and environmental impacts and highlighting the role of foreigners in problems associated with the companies. This illustrates the nationalist nature of the sentiments underlying these representations. Class groupings were pertinent, but rather than being visible in the form of the representations, they played out in the political and economic potentials of the representations, something I expand on in the next section of this article.

What was the nature of this nationalism inspired by the operations of Solomon Taiyo and RD Tuna? This question is perhaps easiest to answer by first mentioning the kinds of nationalism it was not. The kind of nationalism evident in representations of Solomon Taiyo and RD Tuna did not constitute cultural affinity across subnational groupings or a sense of collective effort for a common national goal. It was neither a cultural nor a civic nationalism (Smith I99I), nor a developmentalist nationalism (Desai 2008). At play was a kind of "imagined community" (Anderson I983), but it was a reactive one. Representations of RD Tuna and Solomon Taiyo did not paint a clear picture of what the community was or wanted; rather, the representations were concerned with what the community was against: their exploitation by outsiders. The national identities exhibited in representations of Solomon Taiyo and RD Tuna may thus be described as being negatively constructed in opposition to processes of "development" that are seen as inherently detrimental to the in-group because they are executed by external significant Others. Was this post-developmentalist nationalism, perhaps? Certainly it was antineocolonialist nationalism.

The national identities visible in representations of Solomon Taiyo and $\mathrm{RD}$ Tuna have much in common with the national identities visible in the writings and speeches of key political figures from the independence era, such as Bernard Narakobi (PNG) and Peter Kenilorea (Solomon Islands). Both invoked the idea of the "Melanesian Way," drawing on anticolonial movements in Africa and elsewhere around the world in the preceding decades, to valorize aspects of ethnic identity that differentiate them from the colonizers and neocolonizers (Narakobi I983; Keesing I982).

Interactions with foreign investor companies like RD Tuna and Solomon Taiyo placed people in national collectivities through their logics of production, consumption, and divisions of labor (Foster 2002). For example, both Solomon Taiyo and RD Tuna (in common with most other 
employer organizations in both countries) differentiated employee roles and remuneration along lines of nationality, related to relative levels of national "development." Both companies invested locally because (among other reasons), in these "developing" countries, local labor was cheap. However-and also because of the developing country status-the local population was seen as lacking the skills and knowledge for leading roles within the company, so the latter roles were filled by people from "more developed" countries, where remuneration expectations were correspondingly higher. And because working in a developing country is seen as a hardship post, they were paid even more (Barclay 2004; Barclay and Cartwright 2007). Positions of power and authority, as well as remuneration scales, therefore explicitly placed people (hierarchically) within national groupings. The products of these companies-with an export grade destined for Europe or the United States and the by-products sold in local and regional markets-also grouped people nationally as (more or less wealthy) consumers, a point expanded on in the following section.

The identities "Solomon Islander" and "Papua New Guinean" contained in representations of RD Tuna and Solomon Taiyo thus have several defining features. They were predominantly economically nationalist, mixed in with both narrow subnational and broad regional and global anti-neocolonialist identities, but they were not based on a sense of national ethnic belonging or collective striving for a common goal. They were constructed against processes of development that were managed and owned by Asian foreigners, who were understood as exploitative of Pacific Islander locals. The next section of this article explores the significance of this type of national identity, considering what identifying negatively against foreign investment through stories of corporate wrongdoing means for "development" in Papua New Guinea and Solomon Islands.

\section{Effects of Negative Impact as a Discourse of Identity}

One way to interpret negative stories about Solomon Taiyo and RD Tuna is as a form of resistance. A simple example of this is that vociferous public protests against companies are a form of political pressure that may help bring about desired change. In 2003, RD Tuna was causing pollution in the surrounding area because part of its factory was not connected to the wastewater treatment system and thus was sending untreated wastewater into local waterways. This problem was compounded when the workers' toilets broke down-hundreds of workers were using a nearby field, 
from which runoff entered a stream during rain. Public protests against the wastewater problem at RD Tuna in 2003 led to a government investigation, and by 2004 the company had fixed the toilets and connections to the wastewater treatment plant (Hickey 2003; Dau 2003; Post Courier 2003). ${ }^{11}$ Papua New Guinea and Solomon Islands provincial and national governments have not been proactive in bringing companies to task over environmental problems. Indeed, correspondence among the Noro Town Council, the Western Province Government, concerned residents, and the company over problems with Solomon Taiyo's wastewater in the I990s revealed that there was not the legislative capacity to prosecute the company for causing pollution, even if there had been the executive will. ${ }^{12}$ In twenty-seven years of operation, Solomon Taiyo was never penalized by the government for causing environmental problems. Given the lack of government initiative to address environmental problems arising from these companies, strident public protest was one of the only options for locals seeking redress.

Negative impact stories also served as resistance on the symbolic level. The "Solomon Blue" poem presented earlier in this article is a strong assertion of cultural identity, as are other poems by the same poet that critique development (Sipolo I98I, I986; Makini 2007). By representing these companies as exploiting local people, the symbolic violence of categorization as least-developed countries can be transformed into a kind of symbolic weapon to protest subordination in the world system. The following quote deploys a negative representation of Solomon Taiyo in this way:

[Solomon Taiyo's] local processing is largely export-oriented, whereby the choice tuna meat is bound for foreign markets. What is consumed in the islands is often of poor quality, made from brown flakes (the part of the tuna that ends up as pet food in some Western countries). Such products are nonetheless still a popular food item among Solomon Islanders because of the prohibitive price of the export grade. (Samou I999, I49)

A reader could understand from this passage that Solomon Islanders are eating substandard food and would prefer to eat the light meat canned tuna but cannot afford it. Certainly light meat tuna is more expensive than Solomon Blue flake in Solomon Island shops, and most Solomon Islanders have very limited cash incomes, but it does not necessarily follow that flake meat is poor quality or that Solomon Islanders would prefer light meat. Quality and preference in this case are culturally contingent. The 
brown meat has more blood in it and has a stronger "fishy" flavor and smell, so in cultures where low-smell, lighter-color varieties of fish are preferred, such as the English-speaking world, the dark part of the fish can only be sold as pet food. But the dark meat is no less nutritious, indeed it is probably more so, and in cultures where the strong flavor of skipjack is popular, the dark part of the meat may be enjoyed. Many Solomon Islanders feel the Solomon Blue flake product has more flavor than the light meat. For Solomon Islanders living abroad, Solomon Blue has a status somewhat like Vegemite (a by-product of beer manufacturing) for Australians; it is valued highly as a "taste of home." In 2005, the Supabarn supermarket chain in Canberra, where there is a Melanesian community around diplomatic missions and the universities, was selling Solomon Blue at the same price as light meat tuna.

Deborah Gewertz and Frederick Errington have explored the complex political, economic, and identity issues surrounding Pacific Islanders eating products they know white people refuse to eat or indeed see as only fit for animal consumption (20IO). Solomon Blue and RD Tuna's equivalent flake products could be seen as similar to Gewertz and Errington's lamb flaps in that they are eaten with enjoyment and perform an important national nutritional role, yet, as by-products from the production of white people's food, are troubling to senses of self in postcolonial countries struggling with persistent economic development problems. Gewertz and Errington pointed out, however, that not all foods rejected by white people are equally troubling. They cited canned brined beef brisket, another food Pacific Islanders know white people don't eat, but which is not seen as being "dumped" on Pacific Islanders in the same way as lamb flaps (Gewertz and Errington 2010, I46). Solomon Blue may be more like canned brisket than lamb flaps in this respect-if not for Samou, then at least for the people paying top dollar for it in Canberra.

The following story about relations between villagers and Solomon Taiyo fishing vessels may also be interpreted as a form of protest, in this case about bad treatment of villagers by Solomon Taiyo and the national government Fisheries Department.

[A]s this abundant fishery is "discovered" by more and more Asian ships moving ever southward, locals are noticing the impact of large fishing ships on their catches. A fisher of Lengana village explains: "The Japanese fleet gets permission from the [Solomon Islands] Fisheries Department. The boats come right close to the reefs where our people usually do their fishing. They don't ask permission in the village; they just go there. And villagers are asking: 'Why 
are these people fishing in our sea?' They do not know that the sea is open and that Fisheries can just let anyone fish anywhere....

"And the Japanese fleets do not want to share anything with the villager people. Normally if you fish on that reef, you must share your catch with the villagers. The village elders spoke strongly to them and pointed out their mistakes. So the Japanese people just give a bit of fish, not much.” (Kalgovas 2000)

An interesting difference between this quote and the others presented in this article is that the others, while partial, are not inaccurate, whereas this picture is somewhat exaggerated. Assuming it is a faithful transcription of what the fisher from Lengana (a village on Simbo Island; see map I) said to the reporter, the exaggeration strengthens the sense that this is a representation, with all the social baggage that entails. The system of permission for use of reef and lagoon areas was developed during the I970s and was well established by the early i980s (Blaber, Milton, and Rawlinson 1993). Permission was administered by the Fisheries Department, but any business in Solomon Islands (or Papua New Guinea) must also have local permission or locals will simply not allow the business to go ahead. From the outset of Solomon Taiyo, reefs and lagoons were treated as held under customary tenure, with royalties for fishing payable to local landowners (Kabui 1997). In some cases, there were disputes over who had rights to royalties as landowners, and royalties were never distributed to all villagers because villages included settlers from inland areas, who were not considered landowners. The royalties were not large (in 1999 they were around us $\$ 22$ per vessel per night). For these and other reasons, baitfishing was sometimes opposed from within villages. In these cases, the company would cease using the disputed area because it did not want to risk having expensive equipment damaged by angry villagers. There were enough registered baitgrounds that the company could stop using particular areas without operational difficulties. Sharing fish from the catch was a widespread practice because a small portion of each catch was damaged or consisted of species that were of no commercial value to the company, so crews traded these fish with nearby villages, often in exchange for fresh fruit and vegetables (Barclay 2008). This is not to say that the company was being altruistic. Doing these things cost Solomon Taiyo very little (nothing, in the case of giving bycatch to villagers and of ceasing to use disputed areas) and enabled the company to have easy access to a cheap source of baitfish; thus there was no reason not to oblige. The Solomon Islanders I interviewed in baitfishing communities knew that permission 
of local communities was necessary, that royalties were paid to registered baitground owners, and that trading for or gifting of fish from the vessels was widespread. Nevertheless, stories like this one from the fisher from Lengana persisted. Why?

Beyond protesting the unfair situation whereby a foreign-dominated company could make money from marine resources while villagers had very little opportunity to earn cash, this representation could also have served a more immediate and pragmatic aim. In Solomon Islands and Papua New Guinea, neither the government nor the private sector provide adequate services for health, education, communications, employment, or transportation to the majority of the population. Goods and services have to be won though skillful approaches to appropriate patrons, including aid donors and nongovernmental organizations (Cox 2007). ${ }^{13}$ The reporter to whom the fisher from Lengana told his story was an employee of the conservation nongovernmental organization wwF (World Wide Fund for Nature), which is active in Solomon Islands and funds livelihoods projects as a way of encouraging people not to harvest endangered marine species such as turtles. Creatively manipulating dominant groups' discourses and playing dominant groups against each other provide an avenue for subordinated peoples to achieve their ends (Ramos I998, I6, 98-IOI). Discourses of negative impact from Solomon Taiyo that utilized globally circulating negative images of Asian fisheries may thus have been useful for villagers approaching Western nongovernmental organizations for economic assistance.

In a related vein, discourses of negative impact may be used to leverage benefits from the global nature of contemporary capitalism. Anna Tsing has pointed out the problems of protecting labor and the environment in contemporary forms of "supply chain capitalism," but also noted that positive change may be brought about through bringing to light in the location of consumption the labor exploitation that has gone on in other places to produce those commodities (Tsing 2009). This way of using global networks and communication to ameliorate problems caused by global capital was made famous by Naomi Klein (2000). The "Friends of Kananam" website quoted earlier was no doubt created with this in mind.

Politicians also criticized Solomon Taiyo and RD Tuna, although in their case denunciations of the companies could serve quite different ends. In I 997 Prime Minister Solomon Mamaloni, in the last few months before he lost the government, launched a scathing attack against Solomon Taiyo, 
with an inquiry involving officials from several ministries into accusations of technical incompetence, improper recruitment of foreigners over Solomon Islanders, the sending of contract work overseas unnecessarily, and the exportation of capital. ${ }^{14}$ At that time, the Solomon Islands government had been the major shareholder of Solomon Taiyo for more than a decade, and Mamaloni had been prime minister for much of that period, so any problems with Solomon Taiyo were at least in part his responsibility. Public perceptions of the company as dominated by foreigners, however, enabled him to play the economic nationalist card, distracting attention from the shortcomings of his government.

Negative representations of the companies could thus be used for cynical political aims, but more often they constituted a form of resistance. In some cases the resistance was symbolic, in others it was a concrete tool to achieve change from the government, from nongovernmental organizations, or from the companies themselves.

\section{Anti-, Post-, or locally Appropriate Development?}

Negative representations of the companies also had other effects, one of which was to contribute to the difficult business environment in these countries. Nationalistic attitudes against foreign investment can be one of the intangible obstacles discouraging investment (Cherry 2006; Kim and Lee 2007). Widespread perceptions of the companies as socially and environmentally destructive meant the companies had a lack of goodwill. Negative public images of the companies went hand-in-hand with large amounts of petty sabotage against the companies. Many Solomon Islander interviewees talked of disgruntled villagers damaging the underwater lights, small boats, and nets used for baitfishing. These pieces of equipment were worth tens of thousands of dollars apiece, so such events added considerably to Solomon Taiyo's operating costs. Similarly, RD Tuna had ongoing costs associated with low levels of goodwill. The "Friends of Kananam" quote presented earlier in this article is from a much-publicized website calling for a boycott of RD Tuna products and quoting representatives of the dispossessed landowner groups. A local nongovernmental organization, the Bismark-Ramu Group (BRG), had been working with these groups, although a legal investigation found that BRG had not created the website. In an attempt to counter this negative publicity, RD Tuna took the dispossessed landowner groups and BRG to court, but eventually their case was overturned, and $\mathrm{RD}$ had to pay costs. 
The court action was expensive for RD Tuna and generated negative publicity that had the potential to damage buyer contracts. In the primary end markets for canned tuna in the United States and the European Union, retailers' concern about their reputation for corporate social responsibility means that they have refused to buy canned tuna from sources they fear will damage their reputation (Campling 2008). Following the court action, RD Tuna was nominated by an Australian nongovernmental organization, Friends of the Earth, for a "Public Eye on Davos" award for bad corporate citizenship (Erklärung von Bern nd). Deploying discourses of negative impact globally in this way may achieve desired change in company practices, but equally it may result in investors deciding the situation is "too hard" and withdrawing.

Could the petty damage done to Solomon Taiyo and RD Tuna by narratives of negative impact be characterized as a victory of postdevelopment? Could it be argued that Solomon Islanders and Papua New Guineans did not need or want capitalist development in the form of industrial tuna fishing, with smelly canning factories providing poorly paid work and spoiling their coastal environments? The answer is complicated because, while they had undeniable problems with these companies, people also valued the opportunities the companies brought. People appreciated the chance to earn cash-which is necessary for schooling, health care, and storebought commodities - and wanted the choice to take part in the modern economy. The main cash-earning activity for women around Madang has been selling goods, such as food, in local markets. Women could make around I 50 kina per week in the markets. Women who worked at the RD cannery took home around one-third that amount, but apparently many younger women preferred the prestige of working in a modern factory, in contrast to the market-selling undertaken by their older women relatives. ${ }^{15}$ It is therefore overly simplistic to say that negative representations were part of consistent antidevelopment attitudes. The complicated reality is that Solomon Islanders and Papua New Guineans have valued the opportunities offered by these companies but at the same time have not wholeheartedly embraced foreigner-dominated capitalist enterprise. They want development (in forms appropriate to local society), but they also want less domination by foreigners. Attacks on foreign companies further one part of that desire, while they possibly stymie the other.

Stories of negative impact contribute to the unproductive back-andforth of pro- versus antidevelopment arguments. In the case of RD Tuna, this kind of debate played out in articles and letters to the editor printed 
in two local newspapers, the Post Courier and The National. The Post Courier ran several articles and letters to the editor that were critical of RD Tuna in 2003-2004, while The National, spearheaded by journalist Alfredo Hernandez, published articles that lauded the development achievements of RD Tuna, attacked the groups opposing RD, and denied that their complaints had any validity whatsoever (Post Courier 2003; Puton 2004; Peter 2003; Frank and Niesi 2003; The National 2003; Hickey 2003; Dau 2003). If people want to reform RD Tuna to facilitate more locally appropriate forms of development, this kind of exchange is possibly counterproductive.

Instead, it might be useful to debate what local development might look like and how companies like RD Tuna could be changed to better facilitate it. Morgan Brigg has suggested that locally appropriate political development could draw on wantokism (2009). Wantokism is generally represented by outsiders as an obstacle to good governance, but Brigg showed that by rethinking the fit between wantokism and modern democratic government systems it could actually be used as a check and balance to improve governance. Local economic cultural features and their role in development could be similarly rethought.

Tsing offered an alternative framework for viewing the opportunities offered to Islander employees by companies like Solomon Taiyo and RD Tuna (2009). In analyzing "supply chain capitalism," a type of capitalism that encompasses the global tuna production in which Solomon Taiyo and $\mathrm{RD}$ Tuna are engaged, she found that diversity plays a special role. Companies using global supply chains of contractors make use of this diversity to locate labor-intensive parts of production in places or populations with low labor costs, which is obviously exploitative and undoes the progress made toward improving working conditions by unions in now-wealthy countries in the early and mid twentieth century. But at the same time, capitalists cannot control diversity; in allowing it for their own ends, they enable people working in these supply chains to adapt work for their particular aspirations. In Tsing's framework, "supply chains are not always evil-they also open alternatives-[and] creative alternatives emerg[e] from within the interstices between capitalist and non-capitalist spaces" (2009, I7I). She talked specifically of combining livelihoods with cultural and social goals. Tsing's examples are of farmers and mushroom pickers who are independent contractors rather than employees like Solomon Taiyo and RD Tuna's workers, but her ideas may nonetheless be adapted. 
For example, Solomon Taiyo and RD Tuna management both complained about extra labor costs incurred through high levels of absenteeism in the workforce. Absenteeism had various causes, including difficult living, commuting, and working conditions, but one of the contributing causes was that in Papua New Guinea and Solomon Islands there are strong social obligations and desires to do things other than cash work, and customary tenure gives people viable economic alternatives to full time cash work. Some commentators propose that the solution is to break customary tenure so that Pacific Islanders become wholly dependent on the cash economy (Gosarevski, Hughes, and Windybank 2004). Removing the safety net customary tenure provides against the vagaries of the cash economy would arguably cause great economic hardship, and customary tenure is one of the bulwarks of local cultures, so this is not a way to foster locally appropriate development. An alternative approach would be to find ways to adapt cash activities and customary tenure such that they may coexist more smoothly. A solution along these lines was apparently found for the problem of absenteeism in a Marshall Islands tunaloining plant. Instead of engaging individuals, employment opportunities were extended to family groups. Each family had two or three trained and experienced workers and arranged for one to turn up for each shift, giving the employer assurance of a certain number of bodies, and giving employees flexibility to maintain their lives outside cash work. ${ }^{16}$ This kind of approach might improve on the discourse of negative impact in terms of facilitating locally appropriate development.

\section{Resistance or Reification of Domination?}

Discourses of negative impact may be interpreted as a form of ongoing "colonialism of the mind," in which local ethnic identity is subordinated to outsiders (Kabutaulaka I997). K R Howe has traced the historical development of the idea that Pacific Islanders suffered a "fatal impact" from their contact with Europeans and modernity (1984). The assumption that "European entry into the Pacific meant doom and disaster for the islands' inhabitants" began with early admirers of the noble savages and continued on through social Darwinism and the proposition that the Melanesians were a dying race (Howe 1984, 348). These ideas have persisted despite a generation of Pacific historians who questioned the assumption of omnipotent power on the part of colonials and who, in focusing on the activities of Pacific Islanders themselves, discovered other ways of view- 
ing the changes brought about by contact with Europeans and modernity. Howe argued that "to see Islanders as passive, helpless, and always persecuted and suffering at the hands of Europeans not only excludes modern research findings but, it is now argued, denies the Islanders their essential humanity" ( $1984,35 \mathrm{I}-352$ ). Howe's fatal impact theory shares some central tenets with Marshall Sahlins's "despondency theory" (2000) and Judith Bennett's "mentalities of dependency" (2002). Engagement with foreigners and their modernity has since the I900s been characterized by foreigners bringing modern "cargo," as well as expertise in modern governance and modern business, through colonialism and postcolonial aid programs. For their part, Pacific Islanders have come to expect and rely on this pattern in their relations with foreigners and their modernization projects, be they aid schemes or foreign investment, and to be disappointed when companies do not act as charities (Bennett 2002).

Negative identity construction in responses to Solomon Taiyo and RD Tuna often demonstrated a sense of subordination along these lines. A Pacific Islands Monthly article about sexually transmitted diseases and unplanned pregnancies in Noro cited the executive director of the Solomon Islands Planned Parenthood Association as saying "the majority of these girls have always lived with their parents and have led sheltered lives until they come to Noro-without their parents around and with very limited knowledge and experience to handle men and the new kind of freedom they find in Noro, the girls are at the mercy of any sexually irresponsible male worker." He was quoted as saying that women should be encouraged to "take control" of their lives and make wise decisions, but the overall tone of the article placed responsibility with the company, not the women involved or the social context in which they were raised. For example, the measures suggested for alleviating the situation, including educational workshops and greater provision of contraceptives, were all to be carried out by the company. A Solomon Star article titled "Solomon Taiyo Responsible for Educating its Workers" also discussed naive girls with sheltered upbringings and minimal education being vulnerable in Noro and held the company responsible for fixing this situation. ${ }^{17}$ Neither article included suggestions for local or national government, villages, churches, parents, or schools to prevent or solve social problems. Stories of negative impact from RD Tuna also often accorded the company full responsibility for causing and solving social problems arising in association with company activities. The social impact report on RD Tuna held the company responsible for helping people from the dispossessed 
landowner groups to become successful employees and owners of spin-off businesses (and held it to blame when they did not), and recommended that RD Tuna should fund local schools and local clinics (Sullivan and others 2003, II, 50).

It could be said that given low government capacity to provide social welfare services, it is only practical to rely on the companies as patrons, and indeed governments have often led the call for companies to provide and maintain infrastructure such as roads and services in health, education, and transport. One problem with this approach is that fishing companies are not expert in these areas. Another problem is that this approach locates the potential for generating positive social change within foreign companies rather than in local society. Local communities in Papua New Guinea and Solomon Islands are highly capable of organizing themselves and achieving a great deal, particularly for sporting, cultural, and church activities. Churches are very strong social forces in Noro and have worked to address some of the gender and sexual relations problems arising from Solomon Taiyo activities. Community elders (rather than the under-resourced police) were the main keepers of the peace when violence erupted between groups of young men from different island groups in Noro. To represent the social disruption associated with fishing and processing operations as solely a company responsibility elides these efforts, downplaying the capacities of Solomon Islanders and Papua New Guineans. Representations of multinationals as perpetrators of negative social impact are thus double-edged; they challenge the legitimacy of domination by outsiders, but they also reify the domination through identifying local people as helpless in their engagement with foreign companies.

\section{CONCLUSION}

Complaints about negative impacts from Asian fisheries companies in the Pacific may be seen as representations of the social relations of development. The representations analyzed in this article highlight the economic nationalism underlying ethnic identifications in these contexts. The significance of this analysis is that these relations and identities affect Pacific Islanders' engagement with foreign investment. Solomon Islanders' and Papua New Guineans' primary identification in relation to Asian fisheries investment is that they are negatively impacted by these companies. Histories of outsiders dominating locals and undeniable social and environmen- 
tal problems arising from capitalist enterprises contribute to this position. Stories of negative impact may be useful. Discourses of negative impact may constitute symbolic resistance against inequitable relations, and may also act concretely to enlist patronage to address problems in a context where clientelism is the norm and where the state cannot be relied on to provide much in terms of services or regulation. Governments, nongovernmental organizations, and the companies themselves can be induced to act on problems through public protest about negative impacts.

However, discourses of negative impact also perpetuate disempowered images of local society. Furthermore, discourses of negative impact may feed into antidevelopment approaches to foreign investment; while most Solomon Islanders and Papua New Guineans are not against development, they are dissatisfied with the extent and types of development that have emerged for them thus far. Discourses of negative impact are thus double sided in that they act as resistance against the undesired parts of development, yet can threaten the viability of businesses, including the desired aspects of their operations. Exactly what an ideal Papua New Guinean or Solomon Islands modernity might look like is not yet clear, but it is clear that people want better health, education, transportion, and communication services, along with opportunities to earn cash and chances to participate in modern society, in ways that strengthen rather than diminish ongoing village- and customary tenure-based life. Working out locally appropriate blueprints of modernity and whether/how Asian fisheries companies can contribute to this development may require more openended, and possibly less oppositional dialogue.

THIS PAPER WAS ORIGINALly PRESENTED at a seminar hosted by the State, Society and Governance in Melanesia project at the Australian National University and benefited greatly from audience feedback. Thanks also to Elaine Jeffreys and anonymous reviewers whose comments have significantly improved the paper.

\section{Notes}

I This understanding of representations and discourses in social relations comes from the work of Michel Foucault (1991).

2 See also Barclay 2004 for an earlier version of the argument, which also explores gender and subnational ethnic identities. 
3 Panatina, interview by author, hand noted, Young Women's Christian Association office, Honiara, Solomon Islands, 23 April I999, emphasis added. In line with requirements of the Human Research Ethics Committee of the University of Technology-Sydney, interviewees from Solomon Islands fieldwork in I999 are referred to by pseudonyms.

4 Ziata, interview by author, tape recording, Noro Town Council offices, Noro, Solomon Islands, 22 June I999; I 994 files from Noro Town Council (CF I/28) and Western Province Government (Io/I/I7 I).

5 Kira Kira, matron of Women's Hostel at Baru, interview by author, hand noted, Noro, Solomon Islands, 23 June I999.

6 Kindu, who worked for some years as a health worker for the Western Province, interview by author, tape recording, Munda, Solomon Islands, 6 July I 999.

7 For further discussion on the extent to which negative images of Asians held by white people influence Islander identifications of Asians, as well as the complexity of the "Asian" identity in this context, see Barclay 2007.

8 Deputy general manager, several interviews by author, tape recordings and handwritten notes, Solomon Taiyo Base at Noro, June-July I999.

9 Panatina, interview by author, 23 April 1999.

Io According to RD Tuna management, there were 3,000 locals to 55 expatriates in the cannery and 200 to 36 in the cold store, with the reverse situation on the fleet: around 5 locals to 35 expatriates on fishing vessels.

I I Clarence Hoot, manager of the PNG Investment Promotion Authority (IPA) and member of the government team that investigated RD pollution issues, interview by author, hand noted, IPA offices, Port Moresby, May 2005.

I 2 This correspondence is contained in files of the Noro Town Council (file numbers 8/3/II and 9/I/7) and the Western Province Government (file number IO/I/I 7 I).

I 3 A similar principle has long been employed by Pacific Island governments in the international sphere. During the Cold War, rivalry between the Soviet Union and the United States was utilized to leverage support from the United States (for example, in the I980s by granting fishing access to USSR fleets). Solomon Islands and Papua New Guinea both benefit from the rivalry between the People's Republic of China and Taiwan by gaining aid from the version of China they diplomatically recognize.

I4 Correspondence in 1997 files of the Solomon Islands National Union of Workers and the Western Province Government (IO/I/I 7 I). For discussion about the extent to which the company was guilty of these charges, see Barclay 2008.

I 5 Barry Lalley, interview by author, hand noted, Jais Aben, Madang, Papua New Guinea, May 2005.

I6 Simon Tiller, interview by author, hand noted, Fisheries Department, Kukum, Honiara, Solomon Islands, 5 July 2008. 
I7 "Women News and Views" from the Pacific Islands Monthly (no author, issue number or page number, c.1994) and the Solomon Star article (no title, author, date or page number) were found in the files of Noro Town Council $(8 / 3 / 5)$.

\section{References}

Anderson, Benedict

I983 Imagined Communities: Reflections on the Origin and Spread of Nationalism. London: Verso.

Atkinson, Joel

2009 Big Trouble in Little Chinatown: Australia, Taiwan and the April 2006 Post-Election Riot in the Solomon Islands. Pacific Affairs 82 (I): 47-66.

Barclay, Kate

2004 Mixing Up: Social Contact and Modernization in a Japanese Joint Venture in Solomon Islands. Critical Asian Studies 36 (4): 507-540.

2006 Between Modernity and Primitivity: Okinawan Identity in Relation to Japan and the South Pacific. Nations and Nationalism I2 (I): II 7 -I 37 .

2007 Fishing. Western, Japanese and Islander Perceptions of Ecology and Modernization in the Pacific. The Asia Pacific Journal: Japan Focus. Online journal. http://www.japanfocus.org/-Kate-Barclay/ 2508 [accessed 28 January 20II]

2008 A Japanese Joint Venture in the Pacific: Foreign Bodies in Tinned Tuna. London: Routledge.

Barclay, Kate, and Ian Cartwright

2007 Capturing Wealth from Tuna: Case Studies from the Pacific. Canberra: ANU E Press.

Bennett, Judith

I987 Wealth of the Solomons: A History of a Pacific Archipelago, I80o1978. Pacific Islands Monograph Series 3. Honolulu: Center for Pacific Islands Studies and University of Hawai'i Press.

2002 Roots of Conflict in Solomon Islands. Though Much Is Taken Much Abides: Legacies of Tradition and Colonialism. State Society and Governance in Melanesia Discussion Paper 2002/5. Canberra: Research School of Pacific and Asian Studies, The Australian National University.

Billig, Michael

I995 Banal Nationalism. London: Sage. 
Blaber, S M J, D A Milton, and N J F Rawlinson

I993 Tuna Baitfish in Fiji and Solomon Islands. Workshop Proceedings 52, Suva, I7-I 8 August. Canberra: Australian Council for Interna-

Brigg, Morgan tional Agricultural Research.

2009 Wantokism and State Building in Solomon Islands: A Response to Fukuyama. Pacific Economic Bulletin 24 (3): I48-I6I.

Campling, Liam

2008 FFA Fisheries Trade Briefings (January, March, April). Pacific Islands Forum Fisheries Agency (FFA). Available at http://www.ffa.int/trade

Cherry, Judith _news [accessed 28 April 20I0]

2006 Killing Five Birds with One Stone: Inward Foreign Direct Investment in Post-Crisis Korea. Pacific Affairs 79 (I): 9-27.

Cox, John

2007 Active Citizenship or Passive Clientelism: Thinking About Accountability and Development in Solomon Islands. Paper presented at “Active Citizenship: Making Bottom-Up Accountability Work" conference, Monash University, Australia, 3 July.

Crocombe, Ron

2007 Asia in the Pacific Islands: Replacing the West. Suva: Institute of Pacific Studies, University of the South Pacific.

Dau, John

2003 MP Stirs up Stink over RD Tuna. The National, I October.

Desai, Radhika, editor

2008 Developmental and Cultural Nationalisms. Special issue of Third World Quarterly 29 (3).

Donigi, Peter

2005 EU Should Finance Fish Harvesting Capacities. The National, 23 August

Dureau, Christine

I998 Decreed Affinities: Nationhood and the Western Solomon Islands. The Journal of Pacific History 33 (2): 197-220.

Erklärung von Bern

nd The Public Eye on Davos. Available at http://www.evb.ch/p250033 I 8 .html

Foster, Robert

2002 Materializing the Nation: Commodities, Consumption and Media in Papua New Guinea. Bloomington: Indiana University Press.

Foucault, Michel

I99I The Foucault Reader, edited by Paul Rabinow. London: Penguin Books. 
Frank, Geua, and Peter Niesi

2003 Io,000 Illegals. Post Courier, 2 October.

Friends of Kananam

nd The Kananam Community Say “No!” to RD Tuna. Available at http://lorikeet.and.com.au/RD/rdtuna.html [accessed I 3 May 2009]

Gewertz, Deborah, and Frederick Errington

20I0 Cheap Meat: Flap Food Nations in the Pacific Islands. Berkeley: University of California Press.

Gilroy, Paul

I993 The Black Atlantic: Modernity and Double Consciousness. London: Verso.

Gosarevski, Steven, Helen Hughes, and Susan Windybank

2004 Is Papua New Guinea Viable with Customary Land Tenure? Pacific Economic Bulletin I9 (3): I33-I36.

Hickey, John Tongri

2003 Allow Officials to Check Allegations. The National, 8 October.

Howe, K R

I984 Where the Waves Fall: A New South Sea Islands History from First Settlement to Colonial Rule. Pacific Islands Monograph Series 2. Honolulu: Center for Pacific Islands Studies and University of Kabui, Frank Hawai'i Press; Sydney: George Allen and Unwin.

I997 Crown Ownership of Foreshores and Seabed in Solomon Islands. Journal of Pacific Studies 21:I23-I44.

Kabutaulaka, Tarcisius Tara

I997 I Am Not a Stupid Native: Decolonising Images and Imagination in Solomon Islands. In Emerging from Empire? Decolonisation in the Pacific, edited by Donald Denoon, I65-I7I. Canberra: Division of Pacific and Asian History, Research School of Pacific and Asian Studies, The Australian National University.

Kalgovas, Vicki

2000 The Shark's Children. New Internationalist 325 (July): 23-24.

Keesing, Roger

I982 Kastom in Melanesia: An Overview. Mankind I3 (4): 297-30I.

Kim, Wan-Soon, and You-il Lee

2007 The Korean Economy: The Challenges of FDI-led Globalization. Cheltenham, uk: Edward Elgar.

Klein, Naomi

2000 No Logo: Taking Aim at the Brand Bullies. Ontario: Knopf Canada.

Makini, Jully [Sipolo]

2007 Flotsam and Jetsam. Suva: Institute of Pacific Studies, University of the South Pacific. 
Nandy, Ashis

I988 The Intimate Enemy: Loss and Recovery of Self under Colonialism. Delhi: Oxford University Press.

Narakobi, Bernard

I983 The Melanesian Way. Boroko: The Institute of Papua New Guinea Studies; Suva: Institute of Pacific Studies.

\section{The National} 2003 RD Tuna Has Nothing to Hide. 3 October.

Peter, Brenda 2003 RD Tuna Pollution Allegations. Post Courier, 3 June.

Post Courier 2003 Cannery "Guilty" of Pollution. 27 November.

Puton, Beverly 2004 Local Landowners Upset. Post Courier, I I March.

Ramos, Alcida Rita I998 Indigenism: Ethnic Politics in Brazil. Madison: University of Wisconsin Press.

Reilly, Benjamin 2008 Ethnic Conflict in Papua New Guinea. Asia Pacific Viewpoint 49 (I): I 2-22.

Sachs, Wolfgang, editor

I997 The Development Dictionary: A Guide to Knowledge as Power. London: Zed Books.

Sahlins, Marshall

2000 On the Anthropology of Modernity; or, Some Triumphs of Culture over Despondency Theory. In Culture and Sustainable Development in the Pacific, edited by Antony Hooper, 44-6I. Canberra: Asia Pacific Press.

Samou, Salome

I999 Marine Resources. In Strategies for Sustainable Development: Experiences from the Pacific, edited by John Overton and Regina Scheyvens, I42-I 54. Sydney: University of New South Wales Press.

Sautman, Barry, and Yan Hairong 2008 The Forest for the Trees: Trade, Investment and the China-in-Africa Discourse. Pacific Affairs 8I (I): 9-29.

Sipolo, Jully I98 I Civilized Girl. Suva: South Pacific Creative Arts Society. I986 Praying Parents. Honiara: Aruligo Book Centre.

Smith, Anthony D I99I National Identity. London: Penguin.

Solomon Star

I995 Letter to the Editor, from "a concerned nationalist.” I 6 September. 
Stone, Robert, Lagi Toribau, and Sari Tolvanen 2009 Developing Sustainable and Equitable Pole and Line Fisheries for Skipjack. Amsterdam: Greenpeace International.

Sullivan, Nancy, Thomas Warr, Joseph Rainbubu, Jennifer Kunoko, Francis Akauna, Moses Angasa, and Yunus Wenda

2003 Tinpis Maror: A Social Impact Study of Proposed RD Tuna Cannery at Vidar Wharf, Madang. Madang, PNG: Nancy Sullivan and Associates.

Tsing, Anna

2009 Supply Chains and the Human Condition. Rethinking Marxism 2I (2): $148-176$.

\section{Abstract}

This article explores ethnic identities in representations of tuna fishing and canning companies in Solomon Islands and Papua New Guinea. One point raised by the analysis is that while national identities in these countries are often disrupted by subnational ethnic identities, strong nationalist discourses pervade representations of these companies. The nationalism apparent in responses to these companies is negative, reacting against perceived exploitation by foreigners through narratives of corporate wrongdoing. This article investigates the significance of this style of identification and questions whether the national identities entailed in negative representations of foreign investment constitute resistance against development or a disempowering victim identification that reifies a subordinate position in the world political economy.

KEYWORDS: nationalism, development, postdevelopment, fisheries, Solomon Islands, Papua New Guinea 